\title{
Analisis Kesesuaian Visi, Misi, Tujuan dan Kurikulum Prodi Pendidikan Agama Islam Pascasarjana IAIN Lhokseumawe dan IAIN Curup
}

\section{Ayu Fitria Nur Utami}

Pascasarjana IAIN Surakarta, Indonesia

Email: Ayufitriaa0006@gmail.com

\begin{abstract}
ABSTRAK
Penelitian ini bertujuan untuk mengulas visi, misi, tujuan dan kurikulum Program Studi Pendidikan Agama Islam pada Pasca sarjana IAIN Lhokseumawe dan Pasca sarjana IAIN Curup. Metode penelitian yang digunakan dalam penelitian ini adalah metode studi dokumen, di mana dokumen yang digunakan sebagai bahan penelitan berasal dari web IAIN Lhokseumawe http://pasca.iainlhokseumawe.ac.id dan web IAIN Curup http://pascasarjana.iaincurup.ac.id/. Analisis data yang digunakan yaitu analisis deskriptif kualitatif. Temuan penelitian menunjukan bahwa dalam pengelolaan dan pengembangan lembaga pendidikan tinggi, Program Studi Magister Pendidikan Agama Islam Pasca sarjana Lhokseumawe dan IAIN Curup telah memiliki visi, misi, tujuan, serta kurikulum yang dirumuskan dalam rangka meningkatkan kualitas pendidikan lembaga tersebut. Selain itu, perumusan visi, misi, tujuan, serta kurikulum IAIN Curup dan IAIN Lhokseumawe keduanya memiliki perumusan yang berbeda. IAIN Curup mengharapkan pembelajaran PAI berbasis riset nasional, sedangkan IAIN Lhokseumawe lebih mengharapkan individu unggul dalam pendidikan serta dapat meningkatkan pelayanan bidang PAI berbasis kearifan lokal. Namun di antara perbedaan dua lembaga tersebut dalam perumusan visi, misi dan tujuannya sudah saling berkaitan atau berkesinambungan satu sama lain.

Kata Kunci : Visi, Misi, Tujuan, Kurikulum.
\end{abstract}

\begin{abstract}
This study aims to review the vision, mission, goals and curriculum of the Islamic Religious Education Study Program at the IAIN Lhokseumawe and IAIN Curup Postgraduate Programs. The research method used in this research is the document study method, in which the documents used as research material come from the web http://pasca.iainlhokseumawe.ac.id and http://pascgraduate.iaincurup.ac.id/. The data analysis used is descriptive qualitative analysis. The research findings show that in the management and development of higher education institutions, the Postgraduate Study Program of Islamic Religious Education in Lhokseumawe and IAIN Curup has formulated a vision, mission, objectives, and curriculum in order to improve the educational quality of these institutions. In addition, the formulation of the vision, mission,
\end{abstract}


goals, and curriculum at IAIN Curup has a different formulation with IAIN Lhokseumawe. IAIN Curup wants national research-based PAI learning, while IAIN Lhokseumawe wants individuals to excel in education and be able to improve PAI services based on local wisdom. However, in this difference, the formulation of the vision, mission and goals are interconnected or continuous with each other.

Keywords: Vision, Mission, Goals, Curriculum.

Article history:

Received: 20-12-2019

Revised: 04-12-2020

Accepted: 21-02-2021

Copyright (c) 2020 Utami, Ayu Fitria Nur

\section{PENDAHULUAN}

Perguruan tinggi merupakan lembaga pendidikan tinggi formal yang mempunyai peran penting dalam pembentukan output para lulusannya, maka dari itu dalam proses mengembangkan kualitas suatu instansi lembaga perguruan tinggi dibutuhkannya manajemen yang baik. perguruan tinggi akan berperan dengan optimal apabila didukung oleh sistem manajemen yang terencana yang didukung sumber daya manusia ( SDM) yang bermutu, fasilitas prasarana serta dana/ anggaran pembelajaran yang tepat. Pelaksanaan peraturan serta sistem manajemen yang baik dalam lembaga pendidikan pastinya sangat diperlukan dalam upaya pemaksimalan potensi sekolah sehingga terciptalah pembelajaran yang bermutu. Pembelajaran yang bermutu di dalam lembaga perguruan tinggi dapat tercapai lewat manajemen strategik dalam kenaikan kualitas pembelajaran (Tardian, 2019). Selain itu perguruan tinggi juga dapat melakukan pengembagan kinerja, inovasi dan kreatifitas sebagai landasan dalam merencanakan, menentukan kebijakan-kebijakan yang akan diambil oleh lembaga, serta melaksanakan kegiatan di sebuah lembaga pendidikan. Oleh karena itu dibutuhkan sumber pedoman di lembaga pendidikan yaitu dengan menentukan visi, misi, dan tujuan . efek perbaikan lembaga pendidikan yang bermakna dan perubahan organisasi berpusat pada pengembangan bersama visi, 
misi dan tujuan untuk kemajuan perguruan tinggi (Sukaningtyas, 2017) . Mutu kualitas pada suatu institusi pendidikan harus sebanding dengan output. ataupun kualitas lulusan. Kualitas ataupun mutu sekolah bisa dilihat dari banyaknya siswa yang berprestasi. Perihal tersebut pula bisa dilihat dari pencapaian visi misi yang dihasilkan dari instansi pendidikan (Ali Makhrus, 2019).

Visi merupakan wawasan yang menjadi sumber arahan bagi sekolah dan digunakan untuk penggambaran sekolah dimasa depan yang diinginkan oleh sekolah. Dengan kata lain, visi adalah pandangan jauh kedepan kemana sekolah akan melaju (Mustari, 2014).

Misi adalah pernyataan tentang tujuan organisasi yang diekspresikan dalam produk dan pelayanan yang dapat ditawarkan, kebutuhan yang dapat ditanggulangi, kelompok masyarakat yang dilayani, nilai-nilai yang dapat diperoleh, serta aspirasi dan cita-cita di masa depan (Pramitha, 2016).

Selain visi, misi dan tujuan juga terdapat komponen lain yang berperan penting dalam pendidikan yaitu kurikulum. Kurikulum adalah suatu program pendidikan yang berisikan muatan proses, baik formal ataupun informal yang diperuntukkan untuk pelajar agar mendapatkan pengetahuan serta penjelasan, meningkatkan kemampuan pribadi serta dapat memiliki karakter yang lebih baik serta nilai dengan dorongan sekolah yang berlaku untuk dijadikan pedoman dalam proses pembelajaran agar tercapainya tujuan pendidikan yang telah ditentukan (Arifin, 2011). Dalam proses pendidikan perlu dilaksanakan manajemen kurikulum agar perencanaan, pelaksanaan dan evaluasi kurikulum berjalan dengan efektif, efisien, dan optimal dalam memberdayakan berbagai sumber belajar, pengalaman belajar, maupun komponen kurikulum (Nasbi, 2017). Kurikulum di 
rumuskan guna membentuk kualitas lembaga pendidikan serta membentuk proses perubahan watak peserta didik. Sehingga menghasilkan output sesuai dengan visi, misi dan tujuan.

dari penjelasan di atas, dapat disimpulkan bahwasnnya kurikulum, visi, misi dan tujuan suatu lembaga harus sesuai atau memiliki keterkaitan satu sama lain agar tercapainya kualitas pendidikan yang maju. Namun, terkadang suatu lembaga pendidikan dalam membuat kurikulum kurang memperhatikan visi, misi dan tujuan yang telah dirumuskannya, sehingga antara kurikulum dengan visi, misi dan tujuan tidak sesuai. Untuk mengatasi hal tersebut maka perlunya analisis Visi, misi, tujuan serta kurikulum. Sebagaimana penelitian (Windaningrum, 2019) yang melaksanakan penelitian di SMKN 1 Kedawung Sragen dan SMK

\section{METODE}

Penelitian ini menggunakan metode teks studi tentang visi, misi, tujuan dan kurikulum yang ada
N 1 Bawen Semarang. Menjelaskan Bahwa Visi, misi, tujuan, dan kurikulum memiliki relasi yang kuat. Kedua sekolah tersebut tidak hanya mengedapankan nilai akademik dan prestasi yang diunggulkan namun juga menjadikan peserta didik dalam mendalami ilmu agama dan sosial yang nantinya dapat bersaing di dunia luar di masa globalisasi seperti masa kini. Dalam bukan hanya visi misi tujuan yang dapat mencetak peserta didik peran kurikulum sangatlah penting rancangan atau perangkat yang diterapkan dalam mendidik dan melatih peserta didik yang beriman, cerdas dan trampil sesuai bidang.

Penulis akan menganalisa secara sistematis bagaimana kesesuaian visi, misi, tujuan serta kurikulum Prodi Pendidikan Agama Islam Pascasarjana Lhokseumawe dan IAIN Curup?

pada perguruan tinggi negeri, yaitu pada Pendidikan Agama Islam Pascasarjana Lhokseumawe dan 
IAIN Curup. Teks ditinjau dari alamat web IAIN Lhokseumawe http://pasca.iainlhokseumawe.ac.id dan web IAIN Curup http://pascasarjana.iaincurup.ac.id L. Yang diakses pada tanggal 13 November 2019.

pendekatan yang digunakan berupa kualitatif deskriptif artinya data yang dikumpulkan bukan berupa angka-angka, melainkan data tersebut berdasarkan naskah, memo, dokumen pribadi, dokumen resmi lainnya (Moleong, 2010). menggambarkan suatu

\section{HASIL DAN PEMBAHASAN}

\section{Teori Visi, Misi, Tujuan dan}

\section{Kurikulum}

a. Visi

Pelaksanaan program mutu pendidikan diperlukan beberapa dasar yang kuat, yaitu: Komitmen pada perubahan; Mempunyai visi yang jelas terhadap masa depan; dan Mempunyai rencana yang jelas (Wardah \& Abdul, 2008). visi merupakan pernyataan yang berisikan cita-cita impian sebuah organisasi/perusahaan yang ingin dicapai di masa yang akan datang. perbandingan dua institusi perguruan tinggi yaitu pada ruang lingkup visi, misi, tujuan, dan kurikulum. Sumber data yang sudah terkumpul dianalisis dengan menggunakan metode deskriptif analisis, yaitu mendeskripsikan dan menelaah data dengan maksud menemukan pokok permasalahan dan hubungannya di antara bagianbagian untuk memperoleh pemahaman yang tepat dan menyeluruh tentang pokok bahasan (Sudjarwo, 2011).

Atau juga dikatakan bahwa visi merupakan perumusan kalimat "want to be" dari organisasi atau perusahaan. Kemudian Visi juga disebut dengan hal yang sangat krusial bagi perusahaan untuk menjamin kelestarian dan kesuksesan jangka panjang. Suatu visi harus menjadi inspirasi dan motivasi untuk semua masyarakat di instansi pendidikan terhadap gagasan pikiran yang akan diwujudkan, serta suatu visi diharuskan dapat menghasilkan 
suatu inspirasi terhadap gerak kinerja masyarakat sekolahnya (Fatmawati et al., 2018).

dengan lain kata visi menjadi perihal yang bernilai terhadap instansi pendidikan.

Jadi dapat disimpukan visi adalah gambaran masa depan/ tujuan perusahaan yang ingin dicapai kedepannya, dimana didalam suatu visi terdapat juga nilai-nilai, serta kebutuhan organisasi dimasa depan.

Adapun visi pendidikan adalah pernyataan yang berupa anganangan yang melukiskan suatu identitas lembaga pendidikan yang akan dicapai di masa yang akan datang. Angan-angan ke depan yang akan ada berbagai macam tantangan dan kesempatan yang akan dihadapi nantinya. Dalam merumuskan suatu visi suatu lembaga pendidikan sebelumnya harus mengetahui kemajuan dan masalah yang akan dihadapi di masa depan.

Dalam menentukan visi lembaga pendidikan menurut Akdon
(2006) harus memenuhi indikator, antara lain:

1) Dalam visi tidaklah berupa fakta namun berupa paparan pemikiran tentang sesuartu yang akan dicapai pada masa yang akan datang. Dalam hal ini suatu lembaga dalam perumusan visi harus beriorientasi ke masa yang akan datang, dalam waktu yang lama (jangka waktu)

2) Visi harus bisa memberikan suatu bimbingan, stimulasi, kepada para anggota suatu lembaga pendidikan sehingga terciptanya semangat dan komimen yang tinggi.

3) Adanya usaha yang maksimal sehingga menimbukan keyakinan pada masa yang akan datang menjadi lebih baik dan terarah, sesuai dengan standar dan keinginan masyarakat.

4) Visi lembaga pendidikan harus memuat sesuatu yang menggambarkan tentang standar keunggulan dan harapan yang ingin dijangkau. 
5) Dapat membuat suatu gerakan sehingga terjadi peralihan ke arah yang lebih baik dan terarah.

b. Misi

misi adalah rencana pokok yang menggambarkan alasan lembaga yang dirancang serta diperuntukan pada isu yang menjadi fokus lembaga tersebut. Misi tersusun dari perihal- perihal pokok yang akan dicapai oleh lembaga untuk mendukung keterwujudan visi ( goal utama) yang sudah rumuskan. Statementstatement misi yang disusun secara jelas, sangat diperlukan serta penting dalam menetapkan aktivitas- aktivitas teknis dan dalam merumuskan strategi secara efektif dan efisien (Anisa, 2020). Didalam misi mengandung penjabaran tentang suatu barang dan layanan yang harus memberikan kejelasan apa yang akan dijangkau oleh suatu perkumpulan, serta berisikan suatu cara yang akan dilakukan untuk mencapai harapan yang telah ditentukan. Misi merupakan tugas utama dari suatu lembaga untuk mewujudkan visi atau cita-cita. Misi sekolah ialah sebagai tujuan, tujuan tersebut baik diselenggarakan di satuan pendidikan sekolah maupun diluar sekolah adalah sama (Sukaningtyas, 2017).

Dalam menetapkan suatu misi institusi pendidikan secara umu harus mencantukan harapan yang akan dicapai dan cara yang akan digunakan untuk mencapai tujuan. Perumusan misi akan menjadi landasan kerja yang harus diikuti oleh seluruh komponen dalam institusi pendidikan untuk mewujudkan tujuan yang telah ditentukan (Farikhah, 2018).

Berikut beberapa indikator yang digunakan untuk merumuskan misi lembaga pendidikan (Muhaimin, 2010):

1) Menumbuhkan sikap, perlaiku dan amaliah keagamaan islam

2) Menumbukan semangat belajar ilmu keagamaan Islam

3) Melaksanakan bimbingan dan pembelajaran secara aktif, efektif dan menyenangkan, sehingga setiap siswa dapt 
berkembang secara optimal, sesuai dengan potensi yang dimiliki.

4) Menumbukan semangat keunggulan secara intensif dan daya saing yang sehat, bersih dan indah

5) Mengembangkan lifeskills dalam setiap aktivitas pendidikan.

6) Mengembagkan sikap kepekaan terhadap lingkungan.

c. Tujuan

Tujuan yaitu suatu target yang akan dijangkau oleh individu, kelompok maupun suatu organisasi dimasa yang akan datang dalam waktu yang telah ditentukan (Calam \& Qurniati, 2016). Dalam hubungannya mengenai tujuan pendidikan merupakan sesuatu yang akan dijangkau oleh lembaga pendidikan yang bersangkutan dan kapan tujuan tersebut tercapai (jangka waktu). Tujuan juga dapat dijadikan tolak ukur untuk menilai kinerja lembaga pendidikan tersebut.

Berikut indikator yang digunakan untuk merumuskan tujuan lembaga pendidikan (Calam \& Qurniati, 2016):

1) Tujuan suatu lembaga pendidikan wajib memperhatikan ukuran yang jelas serta bisa diukur agar tujuan sesuai dengan yang disepakati bersama

2) Tujuan lembaga pendidikan harus disesuaikan dengan visi dan misi yang telah di tentukan. Karena ketiga komponen tersebut memilki keterkaitan satu sama lain dan tujuan merupakan pemaparan yang diambil dari visi dan misi.

3) Tujuan lembaga pendidikan merancang aktifitas khusus yang akan dilaksanakan dan waktu diselesaikan. sehingga menghasilkan output yang berkualitas.

\section{d. Kurikulum}

Kurikulum merupakan salah satu alat untuk mencapai tujuan pendidikan, sekaligus merupakan pedoman dalam pelaksanaan pembelajaran pada semua jenis dan jenjang pendidikan (Syafaruddin, 2017). Secara terminologi, 
kurikulum berarti suatu program pendidikan yang berisikan berbagai bahan ajar dan pengalaman belajar yang diprogramkan, direncanakan dan dirancangkan secara sistematika atas dasar normanorma yang berlaku dan dijadikan pedoman dalam proses pembelajaran bagi pendidik untuk mencapai tujuan pendidikan). Menurut Dzakir kurikulum itu memuat semua program yang dijalankan untuk menunjang proses pembelajaran. Program yang dituangkan tidak terpancang dari segi administrasi saja tetapi menyangkut keseluruhan yang digunakan untuk proses pembelajaran. kurikulum juga dapat menunjuk kepada suatu dokumen yang berisi rumusan tentang tujuan, bahan ajar, kegiatan belajar-mangajar, jadwal dan evaluasi. Suatu kurikulum juga dapat mencakup lingkup tertentu, suatu sekolah, suatu kabupaten, propinsi ataupun seluruh negara (Lazwardi, 2017).

Berikut beberapa kriteria dalam merumuskan (Dzakir, 2010) kurikulum:

1) Isi dari kurikulum harus sesuai, tepat, dan bermakna bagi perkembangan peserta didik.

2) Isi kurikulum, harus menggambarkan fakta sosial dengan tuntutan kehidupan

3) Isi kurikulum, mendukung pencaapian visi, misi dan tujuan tujuan yang kemprehensif, yang berarti mengandung asek intelektual, moral dan sosial secara seimbang

4) Isi kurikulum harus mengandung pengetahuan ilmiah yang telah teruji kebenarannya sehingga tidak meyesatkan peserta didik

5) Isi kurikulum harus mengandung bahan yang jelas artinya teori, prinsip, dan konsep yang terdapat didalamnya bukan hanya informasi faktual. 
2. Ulasan Analisis Kesesuaian Visi, Misi, Tujuan dan Kurikulum Prodi Pendidikan Agama Islam Pascasarjana IAIN Lhokseumawe dan IAIN Curup Sebelum memasuki pembahasan mengenai analisis visi, visi, misi dan kurikulum pada Prodi Pendidikan
Agama Islam Pascasarjana Lhokseumawe dan IAIN Curup seyogyanya kita mengetahui sejarah dan alamat pascasarjana IAIN Lhokseumawe dan IAIN Curup.

\section{Tabel 1 Sejarah IAIN Lhokseumawe dan IAIN Curup}

\begin{tabular}{|c|c|}
\hline IAIN Lhokseumawe & IAIN Curup \\
\hline $\begin{array}{l}\text { Pascasarjana IAIN Lhokseumawe telah } \\
\text { berdiri sejak tahun } 2012 \text { melalui Surat } \\
\text { Keputusan Direktur Jenderal Pendidikan } \\
\text { Islam Kementerian Agama RI dengan } \\
\text { Nomor : } 2346 \text { Tahun } 2012 \text {. Program } \\
\text { Pascasarjana ini memfokuskan untuk } \\
\text { pengembangan dan pengamalan nilai-nilai } \\
\text { keislaman serta mengoptimalisasi dan } \\
\text { mengaktualisasikan berbagai bidang } \\
\text { teknologi dan seni dalam penyiaran } \\
\text { keislaman, pendidikan Islam, manajemen } \\
\text { pendidikan dan hukum Islam. }\end{array}$ & $\begin{array}{l}\text { Pendirian Pascasarjana merupakan obsesi } \\
\text { seluruh civitas akademika yang pada saat itu } \\
\text { masih bernama Pascasarjana STAIN Curup, } \\
\text { yang sudah tertuang dalam Rencana Induk } \\
\text { Pengembangan (RIP) dan Master Plan STAIN } \\
\text { Curup tahun 2007/2011-2012/ } 2016 . \\
\text { Kemudian lahirlah Surat Keputusan Direktur } \\
\text { Jenderal Pendidikan Islam nomor } 6271 \\
\text { Tahun } 2014 \text { tanggal 05 November } 2014 \\
\text { tentang Izin Penyelenggaraan Pascasarjana } \\
\text { Program Magister Pada STAIN Curup. Atas } \\
\text { dasar keputusan ini, maka pada Tahun } \\
\text { Akademik 2014/2015 STAIN Curup secara } \\
\text { resmi mulai membuka Pascasarjana, dengan } \\
\text { Program Studi Manajemen Pendidikan Islam } \\
\text { dengan bidang kajian Manajemen Madrasah. } \\
\text { Namun, selang setahun, Pascasarjana STAIN } \\
\text { Curup menambah Program Studi Baru yaitu } \\
\text { Program Studi Pendidikan Agama Islam dan } \\
\text { Hukum Keluarga Islam. }\end{array}$ \\
\hline
\end{tabular}




\section{Tabel 2 Alamat Pascasarjana IAIN Lhokseumawe dan IAIN Curup IAIN Lhokseumawe IAIN Curup}

Jalan Banda Aceh-Medan, Buket Rata. Kota Lhokseumawe. Kode pos: 24352
Jalan Dr. AK Gani No 01, Curup,

Dusun Curup, Curup Utara Kabupaten

Rejang Lebong, Bengkulu kode pos 39119

Kedua perguruan tinggi tersebut merupakan suatu instansi dibawah naungan Kementerian Agama RI. Dalam pendiriannya kedua instansi tersebut tergolong belum lama didirikan dilihat dari tahun berdirinya. Walaupun tergolong baru intansi tersebut mampu berkembang dengan baik sehingga dapat dikenal masyarakat luas.

Tabel 3 Visi Program Pascasarjana PAI

\section{IAIN Lhokseumawe}

Unggul dalam Pendidikan,Terdepan dalam Penelitian, dan Prima dalam Pelayanan di bidang pendidikan agama Islam berbasis kearifan lokal ditingkat nasional pada tahun 2021
IAIN Curup

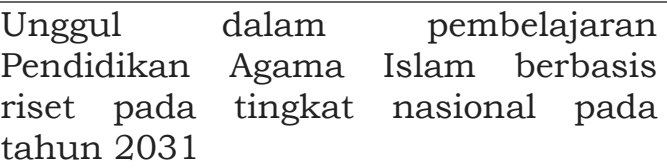

Dalam pengelolan suatu lembaga atau instansi diperlukannya kurikulum yang selaras dengan visi, misi dan tujuan yang telah ditentukan hal tersebut dapat menuntukan karakteristik suatu lembaga tersebut.

Seperti dalam penelitian ini, yang membahas tentang keselarasan atau kesesuaian visi, misi, tujuan serta kurikulum pada prodi Pendidikan Agama Islam Pasca
Sarjana IAIN Lhokseumawe dan IAIN Curup

Dari tabel diatas dijelaskan tentang visi pada prodi Pendidikan Agama Islam Pasca Sarjana IAIN Lhokseumawe dan IAIN Curup. dari visi yang dipaparkan diatas Berdasarkan indikator pada perumusan visi apabila dikaitkan dengan visi dari kedua lembaga pendidikan tersebut maka dapat dianalisis persamaannya sebagai berikut: 
1) memiliki paparan yang spesifik mengenai pemikirannya terhadap masa depan. IAIN Lhokseumawe memiliki harapan bahwasanyan menginginkan prodi Pendidikan Agama Islam menjadi prodi yang unggul dalam pendidikan, terdepan dalam penelitian, dan prima dalam pelayanan, kemudian IAIN Curup mempunyai harapan agar prodi Pendidikan Agama Islam nantinya dapat unggul dalam pembelajaran berbasis riset ada tingkat nasional.

2) sama-sama menginginkan pencapaian yang unggul, oleh karena itu mereka berupaya dalam memberikan stimulasi, kepada para anggota dan mahasiswanya.

3) memiliki persamaan berupa melakukan usaha yang berorientasi kemasa depan agar menghasilkan output seperti IAIN Lhokseumawe yang memiliki harapan Terdepan dalam Penelitian, dan Prima dalam Pelayanan di bidang pendidikan agama Islam, kemudian IAIN Curup yang memiliki harapan menghasilkan pembelajaran Pendidikan Agama Islam berbasis riset pada tingkat nasional.

4) memiliki kesamaan yaitu memuat sesuatu yang menggambarkan tentang masa depan yang akan diraih. Dan memiliki harapan yang ingin dijangkau.

5) memiliki jangka waktu pencapaian visi, IAIN Lhokseumawe memiliki jangka waktu sampai tahun 2021 dan IAIN Curup memiliki jangka waktu pencapaian visi sampai tahun 2031.

Adapun misi Pendidikan Agama Islam Pasca Sarjana IAIN Lhokseumawe dan IAIN Curup adalah sebagai berikut. 
Tabel 4 Misi Program Pascasarjana PAI

\section{IAIN Lhokseumawe}

1. Menghasilkan lulusan yang unggul di bidang pengembangan kurikulum pendidikan agama Islam berbasis kearifan lokal.

2. Melakukan dan mengembangkan penelitian multidisipliner dan interdisipliner yang unggul di bidang pengembangan kurikulum pendidikan agama Islam sesuai dengan perkembangan ilmu pengetahuan dan tuntutan stakeholder.

3. Melakukan dan mengembangkan pengabdian masyarakat di bidang pengembangan kurikulum pendidikan agama Islam berbasis kearifan lokal.

4. Menjalin kerjasama lintas sektoral untuk peningkatan kualitas pendidikan, penelitian, pengabdian dan manajerial.

5. Meningkatkan kualitas pelayanan publik yang profesional berbasis ICT

\section{IAIN Curup}

1. Mengembangkan proses pembelajaran tingkat magister yang memiliki kompetensi dalam bidang pembelajaran agama, pengembangan kurikulum, serta pengelolaan lembaga pendidikan berbasis riset dan tekhnologi pendidikan.

2. Menyelenggarakan proses pendidikan dan pengajaran yang berbasis tekhnologi pendidikan untuk melahirkan sarjana tingkat magister yang memiliki kemamuan instrumental dan model tioritik dalam bidang pembelajaran dan pengelolaan pendidikan.

3. Memiliki kemampuan teknis dalam mengembangkan model evaluasi pembelajaran berbasis tekhnologi pendidikan dengan penguasaan berbagai instrumen yang relevan sehingga ketrampilan dan kemampuan berdaya guna baik sekolah atau institusi tempat mereka bekerja maupun untuk perbaikan sektor pendidikan secara lebih besar dalam skala daerah, regiaonal atau nasional.

4. Membekali kemampuan dalam ilmu pendidikan, ilmu agama Islam, ilmu sosial, humaniora maupun berbagai model penelitian kebijakan yang relevan
Selain merumuskan suatu visi untuk mencapai

tujuan, diperlukannya suatu perumusan misi agar visi dapat di capai. Dengan misi yang telah dipaparkan diatas maka dapat jelaskan bahwasanya prodi pendidikan Agama Islam Pasca sarjana IAIN Lhokseumawe dan IAIN Curup
Berdasarkan indikator pada perumusan misi apabila dikaitkan dengan misi dari kedua lembaga pendidikan tersebut maka dapat dianalisis sebagai berikut:

1. Dalam perumusan misi kedua lembaga perguruan tinggi Islam tersebut belum mencakup harapan tentang output yang 
dihasilakan dari mahasiswa yaitu menumbuhkan sikap, perilaku amalaiah keagamaan Islam dilihat dari misi kedua lembaga tersebut lebih kepada output mahasiswa dalam bidang ketrampilan dalam mengembangkan diri. Yaitu menghasilkan lulusan yang unggul bidang pengembangan kurikulum pendidikan agama Islam berbasis kearifan lokal bagi IAIN Lhokseumawe sedangkan untuk IAIN Curup mengingionkan output

2. Dalam indikator menumbuhkan semanagat belajar ilmu dan keagamaan islam. Dua lembaga pendidikan tersebut dalam perumusan misi sudah terpenuhi. Dapat dilihat dari tabel diatas bahwasannya untuk IAIN Lhoksumawe meninginkan semangat belajar ilmu keagamaan Islam melalui kurikulum pendidikan agama Islam berbasis kearifan lokal sedangkan IAIN Curup membekali mahasiswanya melalui kurikulum pe ndidikan agama Islam berbasis tekhnologi.

3. Misi yang tercantum pada prodi pendidikan Agama Islam Pasca sarjana IAIN Lhokseumawe dan IAIN Curup sudah menggambarkan mengenai pelaksanaan bimbingan dan pembelajaran secara aktif, efektif dan menyenagkan. Dalam pelaksanaan pembelajaran IAIN Lhoksumawe melaksanakan dan mengembangkan penelitian multidisipliner dan interdisipliner yang unggul di bidang pengembangan kurikulum pendidikan agama Islam. Sedangkan untuk IAIN Curup melaksanakan proses pendidikan dan pengajaran yang berbasis tekhnologi pendidikan.

4. Dalam perumusan misi kedua lembaga perguruan tinggi Islam tersebut sudah mencakup harapannya yaitu menumbuhkan semangat keunggulan dan daya saing 
yang sehat dapat dilihat IAIN Lhoksumawe memiliki harapan keunggulan

dalam

melaksanakan pengembangan penelitian multidisipliner dan interdisipliner, melakukan dan mengembangkan pengabdian masyarakat di bidang pengembangan kurikulum serta dapat bekerjasama dengan lintas sektoral. Sedangkan IAIN Curup memiliki harapan keunggulan yang lebih mengarah kepada tekhnologi yaitu meliputi penyelenggaraan proses pendidikan dan pengajaran yang berbasis tekhnologi pendidikan, serta pengembangan model evaluasi pembelajaran berbasis tekhnologi pendidikan. dalam perumusan misi kedua lembaga tersebut sudah memuat pengembanagan lifeskills yaitu IAIN Lhoksumawe menginginkan output berupa Menghasilkan lulusan yang unggul di bidang pengembangan kurikulum
5. pendidikan agama Islam berbasis kearifan lokal sedangkan unuk IAIN Curup menginginkan outpun lulusannya berupa kemampuan teknis dalam mengembangkan model evaluasi pembelajaran berbasis tekhnologi pendidikan dengan penguasaan berbagai instrumen yang relevan sehingga ketrampilan dan kemampuan berdaya guna baik sekolah atau institusi tempat mereka bekerja.

6. Dalam pengembangan sikap kepekaan terhadap lingkungan IAIN Lhosumawe sudah merumuskan misi berupa Melakukan dan mengembangkan pengabdian masyarakat di bidang pengembangan kurikulum pendidikan agama Islam berbasis kearifan lokal serta mekakukan kerjasama lintas sektoral. namun untuk IAIN Curup belum mencakup sikap kepekaanya terhadap lingkungan dilihat dari misi 
yang dirumuskan IAIN curup hanya berfokus kepada output yang akan dihasilkan kedepannya.

Dari analisis diatas dapat disimpulkan bahwasanya misi yang dirumuskan kedua lembaga tersebut memiliki beberapa kebijakan yang dapat mewujudkan visinyaya yaitu melaksanakan pelatihan tidak hanya melalui kempetensi akademik saja namun juga terdapat pelatihan pengembangan teknis agar kemampuan bidang pendidikan agama Islam dapat berkembang dengan baik. Walaupun memiliki kebijakan yang sama yaitu menghasilkan lulusan yang baik namun kedua instansi tersebut memiliki karakteristik yang berbeda - Dalam perumusannya IAIN
Lhoksumawe

lebih

pembentukan

mahasiswanya

pengembangan

pendidikan agama Islam berbasis kearifan lokal. Sedangkan untuk IAIN Curup lebih kepada keahlian mahasiswanya dalam hal tekhnologi pendidikan.

Sebuah lembaga tentunya memiliki tujuan yang ingin dicapai, dan tujuan tersebut akan dikembangkan dengan berbagai cara melalui kegiatan-kegiatan produktif sehingga apa yang diinginkan dapat tercapai (Istiqomah, 2020). Adapun tujuan prodi pendidikan Agama Islam Pasca sarjana IAIN Lhokseumawe dan IAIN Curup adalah sebagai berikut.

Tabel 5 Tujuan Program Pascasarjana PAI

1. Terwujudnya lulusan yang unggul di bidang pengembangan kurikulum pendidikan agama Islam berbasis kearifan lokal ditingkat nasional dan internasional.

2. Terlaksana penelitian multidisipliner dan interdisipliner yang unggul di bidang pengembangan kurikulum pendidikan agama Islam sesuai dengan perkembangan ilmu pengetahuan dan tuntutan stakeholder.

3. Terlaksana pengabdian masyarakat di

\section{IAIN Curup}

1. Tercapainya hasil pembelajaran pada program studi di bidang Pendidikan Agama Islam yang beriman, bertaqwa, berakhlaq terpuji, profesional dan mamu bersaing dalam sekala nasional.

2. Tercapainya hasil pembelajaran pada program studi dibidang penelitian berupa riset dan karya ilmiah berbasis tekhnologi pendidikan dibidang Pendidikan Agama Islam terkini untuk 
bidang pengembangan kurikulum pendidikan agama Islam berbasis kearifan lokal.

4. Ternjalin kerjasama lintas sektoral untuk peningkatan kualitas pendidikan, penelitian, pengabdian dan manajerial.

5. Peningkatan kualitas pelayanan publik yang profesional berbasis ICT

dimanfaatkan bagi pengembangan ilmu, pendidikan serta pemecahan masalah prmbrlajaran berbasis tekhnologi kepada masyarakat.

3. Tercapainya hasil pengembangan kondusif dalam tata kelola yang lebih otonom, sehat, berbasis tekhnologi informasi dan menjadi institusi nasional ysng memiliki daya saing.

4. Terjalinnya kerja sama pengembangan institusional, pendidikan dan penelitian baik ditingkat regional, nasional, maupun pada tingkat internasional untuk mempercepat visi atau misi.

Dari tabel diatas dijelaskan tentang tujuan prodi Pendidikan Agama Islam Pasca Sarjana IAIN Lhokseumawe dan IAIN Curup. dari tujuan yang dipaparkan diatas Berdasarkan indikator pada perumusan tujuan apabila dikaitkan dengan tujuan dari kedua lembaga pendidikan tersebut maka dapat dianalisis sebagai berikut:

1. Tujuan yang tercantum pada prodi pendidikan Agama Islam Pasca sarjana IAIN Lhokseumawe dan IAIN Curup sudah memperhatikan ukuran yang jelas dibuktikan dari cara mereka dalam mengembangkan kualitas pelayanan dan kualitas sumber daya manusia.

2. Tujuan yang tercantum dalam prodi pendidikan Agama Islam
Pasca sarjana IAIN Lhokseumawe dan IAIN Curup telah memiliki kesesuain dengan visi misi yang telah ditentukan. adapun tujuan pertama sampai kelima dalam prodi pendidikan Agama Islam Pasca sarjana IAIN Lhokseumawe merupakan realisasi dari misi yang pertama sampai kelima yang saling berkaitan yaitu Menghasilkan lulusan yang unggul, Melakukan dan mengembangkan penelitian, Melakukan dan mengembangkan pengabdian masyarakat, Menjalin kerjasama, serta meningkatkan kualitas pelayanan. Begitupun juga dengan tujuan pada prodi pendidikan Agama Islam Pasca sarjana IAIN Curup tujuan pertama sampa keempat 
merupakan realisasi terhadap misi yang pertama samai keempat yang saling berkaitan yaitu meliputi Mengembangkan proses pembelajaran tingkat magister , Menyelenggarakan proses pendidikan dan pengajaran yang berbasis tekhnologi , Memiliki kemampuan teknis dalam mengembangkan model evaluasi pembelajaran, Membekali kemampuan dalam ilmu pendidikan, ilmu agama Islam, ilmu sosial, humaniora.

3. Tujuan yang tercantum dalam prodi pendidikan Agama Islam Pasca sarjana IAIN Lhokseumawe dan IAIN Curup. Sama-sama memiliki perancangan aktifitas khusus yang akan dilaksanakan dan waktu diselesaikan. pada IAIN Lhokseumawe 2021 dan IAIN curup pada tahun 2031.

\section{a. Struktur Kurikulum (Body Of Curriculum) Program Studi Pendidikan Agama Islam IAIN Curup}

1) Mata Kuliah Pascasarjana dan Mata Kuliah Pilihan

\begin{tabular}{|c|c|c|c|c|c|c|c|}
\hline \multirow[t]{2}{*}{ No } & \multirow[t]{2}{*}{ MATA KULIAH } & \multirow[t]{2}{*}{ SKS } & \multicolumn{4}{|c|}{ SEMESTER } & \multirow[t]{2}{*}{ KET } \\
\hline & & & 1 & 2 & 3 & 4 & \\
\hline 1 & Academic Writing & 2 & $\sqrt{ }$ & & & & \\
\hline 2 & ICT Pendidikan & 2 & $\sqrt{ }$ & & & & \\
\hline 3 & Bahasa Arab & 2 & & $\sqrt{ }$ & & & \\
\hline 4 & Komunikasi Publik & 2 & & $\sqrt{ }$ & & & \\
\hline 5 & Komunikasi Publik & 2 & & & $\sqrt{ }$ & & \\
\hline \multirow[t]{2}{*}{6} & PAI Berbasis Multikultural & 2 & & & $\sqrt{ }$ & & \\
\hline & JUMLAH SKS & 12 & & & & & \\
\hline
\end{tabular}

2) Mata kuliah Wajib

Tabel 7 Mata Kuliah Wajib IAIN Curup

\begin{tabular}{lllllll}
\hline No & MATA KULIAH & SKS & \multicolumn{2}{c}{ SEMESTER } & \multicolumn{3}{c}{ KET } \\
\cline { 3 - 6 } & & & 1 & 2 & 3 & 4 \\
\hline $\mathbf{1}$ & Sejarah Pemikiran Pendidikan Islam & 2 & $\sqrt{ }$ & & \\
\hline $\mathbf{2}$ & Teori Belajar \& Pembelajaran PAI & 3 & $\sqrt{ }$ & & \\
\hline
\end{tabular}




\begin{tabular}{|c|c|c|c|c|c|}
\hline 3 & Metodologi Penelitian Kualitatif PAI & 2 & $\sqrt{ }$ & & \\
\hline 4 & Metodologi Penelitian Kuantitatif PAI & 2 & $\sqrt{ }$ & & \\
\hline 5 & Teknologi Pendidikan & 3 & $\sqrt{ }$ & & \\
\hline 6 & Pengembangan Kurikulum PAI & 3 & $\sqrt{ }$ & & \\
\hline 7 & Tafsir dan Hadis Tarbawi & 3 & & $\sqrt{ }$ & \\
\hline 8 & Filsafat Pendidikan Islam & 2 & & $\sqrt{ }$ & \\
\hline 9 & Perencanaan Sistem Pembelajaran PAI & 3 & & $\sqrt{ }$ & \\
\hline 10 & Pembelajaran PAI & 3 & & $\sqrt{ }$ & \\
\hline 11 & Sistem Penjamin Mutu PAI & 3 & & $\sqrt{ }$ & \\
\hline 12 & Pengembangan Materi Pembelajaran PAI & 2 & & $\sqrt{ }$ & \\
\hline 13 & Psikologi Pendidikan Islam & 2 & & & $\sqrt{ }$ \\
\hline 14 & Pengembangan Media Pembelajaran PAI & 3 & & & $\sqrt{ }$ \\
\hline 15 & Evaluasi Pembelajaran PAI & 3 & & & $\sqrt{ }$ \\
\hline 16 & $\begin{array}{l}\text { Pengembangan Bahan dan Sumber Belajar } \\
\text { PAI }\end{array}$ & 3 & & & $\sqrt{ }$ \\
\hline 17 & Metodologi Mengajar PAI & 2 & & & $\sqrt{ }$ \\
\hline \multirow[t]{2}{*}{18} & Tesis & 6 & & & $\sqrt{ }$ \\
\hline & Jumlah total SKS & 50 & & & \\
\hline
\end{tabular}

\section{b. Struktur Kurikulum (Body of Curriculum) Program Studi Pendidikan Agama Islam IAIN Lhokseumawe}

1) Mata kuliah pilihan

Tabel 8 Mata Kuliah Pilihan IAIN Lhokseumawe

\begin{tabular}{|c|c|c|c|c|c|c|c|}
\hline \multirow[t]{2}{*}{ No } & \multirow[t]{2}{*}{ MATA KULIAH } & \multirow[t]{2}{*}{ SKS } & \multicolumn{4}{|c|}{ SEMESTER } & \multirow[t]{2}{*}{ KET } \\
\hline & & & 1 & 2 & 3 & 4 & \\
\hline 1 & Inovasi Bahan Ajar PAI & 3 & & $\sqrt{ }$ & & & \\
\hline 2 & Antropologi Pendidikan Aceh & 3 & & & $\sqrt{ }$ & & \\
\hline 3 & Psikologi Pendidikan Agama Islam & 3 & & & $\sqrt{ }$ & & \\
\hline \multirow[t]{2}{*}{4} & Konseling Islam & 3 & & & $\sqrt{ }$ & & \\
\hline & J umlah Total SKS & 12 & & & & & \\
\hline
\end{tabular}

2) Mata kuliah Wajib

Tabel 9

Mata Kuliah Wajib IAIN Lhokseumawe

\begin{tabular}{|c|c|c|c|c|c|c|c|}
\hline \multirow[t]{2}{*}{ No } & \multirow[t]{2}{*}{ MATA KULIAH } & \multirow[t]{2}{*}{ SKS } & \multicolumn{4}{|c|}{ SEMESTER } & \multirow[t]{2}{*}{ KET } \\
\hline & & & 1 & 2 & 3 & 4 & \\
\hline 1 & Tafsir Tematik & 3 & $\sqrt{ }$ & & & & \\
\hline 2 & Hadits Tematik & 3 & $\sqrt{ }$ & & & & \\
\hline 3 & Filsafat Ilmu & 3 & $\sqrt{ }$ & & & & \\
\hline 4 & Sejarah Pemikiran dan Peradaban Islam & 3 & $\sqrt{ }$ & & & & \\
\hline 5 & Sejarah Sosial Pendidikan Islam & 3 & $\sqrt{ }$ & & & & \\
\hline 6 & Bahasa Inggris & 0 & $\sqrt{ }$ & & & & \\
\hline 7 & Metodologi Penelitian & 3 & & $\sqrt{ }$ & & & \\
\hline
\end{tabular}




\begin{tabular}{lllll}
\hline $\mathbf{8}$ & Filsafat Pendidikan Islam & 3 & $\sqrt{ }$ \\
\hline $\mathbf{9}$ & $\begin{array}{l}\text { Analisis Kurikulum PAI Berbasis Kearifan } \\
\text { lokal }\end{array}$ & 3 & $\sqrt{ }$ & \\
\hline $\mathbf{1 0}$ & Pengembangan Model Pembelajaran PAI & 3 & $\sqrt{ }$ \\
\hline $\mathbf{1 1}$ & Bahasa Arab & 0 & $\sqrt{ }$ & \\
\hline $\mathbf{1 2}$ & $\begin{array}{l}\text { Pengembangan Teknologi Informasi } \\
\text { pembelajaran PAI }\end{array}$ & 3 & $\sqrt{ }$ \\
\hline $\mathbf{1 3}$ & Pengembangan Evaluasi Pembelajaran PAI & 3 & \multicolumn{2}{|}{} \\
\hline $\mathbf{1 4}$ & Desain Perencanaan Pembelajaran PAI & 3 & $\sqrt{ }$ \\
\hline $\mathbf{1 5}$ & Seminar Proposal Tesis & 0 & $\sqrt{ }$ \\
\hline $\mathbf{1 6}$ & Tesis & 6 & $\sqrt{ }$ \\
\hline & Jumlah total SKS & 42 & & \\
\hline
\end{tabular}

Dari tabel diatas dijelaskan tentang kurikulum pasca sarjana prodi Pendidikan Agama Islam Pasca Sarjana IAIN Lhokseumawe dan IAIN Curup. dari kurikulum yang dipaparkan diatas Berdasarkan indikator pada perumusan kurikulum apabila dikaitkan dengan tujuan dari kedua lembaga pendidikan tersebut maka dapat dianalisis sebagai berikut:

1. Dalam kurikulum yang telah dirumuskan pasca sarjana prodi Pendidikan Agama Islam Pasca Sarjana IAIN Lhokseumawe dan IAIN Curup sudah sesuai dan tepat dalam mengembangkan

mahasiswanya dalam mewujudkan tujuannya, yang dibuktikan dalam mata kuliah Teori Belajar \& Pembelajaran
PAI, Pengembangan Kurikulum PAI, Pembelajaran PAI, Perencanaan Sistem Pembelajaran PAI, Pengembangan Materi Pembelajaran PAI dan lain-lain yang terdeskripsikan dalam mata kuliah wajib IAIN curup. Kemudian mata kuliah Pengembangan Teknologi Informasi pembelajaran PAI, Pengembangan Evaluasi Pembelajaran PAI, Desain Perencanaan Pembelajaran PAI,Analisis Kurikulum PAI Berbasis Kearifan lokal, Pengembangan Model Pembelajaran PAI dan lain mata kuliah tersebut terdeskirsikan dalam kurikulum prodi PAI pasca sarjana IAIN Lhokseumawe. Mata kuliah yang telah 
dirumuskan tersebut dibentuk guna untuk mempersiapkan mahasiswa pasca sarjana untuk mengembangkan kompetensinya dalam mengajar.

2. Isi dalam kurikulum IAIN Curup dan IAIN Lhokseumawe telah menggambarkan fakta sosial tergambarkan dari kurikulum yang dirumuskan yang bertujuan agar dapat mempersiapkan output yang berkualitas karena pada faktanya dimasyarakat guru kurang efektif dalam menjalankan proses pembelajaran PAI.

3. Isi dalam kurikulum IAIN Curup dan IAIN Lhokseumawe sudah sesuai dengan visi, misi dan tujuan yang ditentukan digambarkan dari hadirnya mata kuliah ICT Pendidikan, Komunikasi Publik dan mata kuliah prodi pendidikan Agama Islam yang terdapat diIAIN Curup ini sudah sesuai dengan visi, misi dan tujuannya yaitu mengembangkan pembelajaran PAI berbasis riset tekhnologi. Kemudian mata kuliah PAI pasca sarjana IAIN Lhokseumawe yang meliputi Antropologi Pendidikan Aceh,Analisis Kurikulum PAI Berbasis Kearifan lokal, Metodologi Penelitian dan lainlain yang menyangkut tentang pengembangan pembelajaran PAI suadah sesuai dengan perumusan visi, misai dan tujuan yaitu mengembangkan pendidikan dalam penelitian serta mengembangkan pelayanan PAI berbasis kearifan lokal.

4. Dalam isi kurikulum yang telah dirumuskan IAIN Curup dan IAIN Lhokseumawe telah teruji kebenatannya terlihat dari outut yang dihasilkan dari mahasiswanya.

5. Kurikulum dalam IAIN Curup dan IAIN Lhoksuemawe telah mengandung bahan yang jelas tergambarkan dalam penerapan matakuliah yang dilaksanakan para dosen 
Perbedaan kurikulum diantara IAIN Curup dan IAIN Lhokseumawe tergambarkan melalui perumusan mata kulliah yang diterapkan. IAIN Curup dalam mata kuliah pilihan lebih menginkan output mahasiswa yang bertekhnologi melalui embelajaran ICT sedangkan IAIN Lhokseumawe lebih mengharakan output berupa individu yang mennyukai kearifan lokal daerahnya kemudian perbedaan lainya terlihat

\section{Kesimpulan}

Dari pembahasan yang telah dijelaskan dapat disimpulkan bahwasnnya dalam menentukan kurikulum harus diselaraskan dengan visi, misi dan tujuan. Seperti perumusan visi, misi, tujuan, serta kurikulum ada IAIN Curup dan IAIN Lhokseumawe keduanya memiliki perumusan yang berbeda IAIN Curup ingin mengharapkan pembelajaran PAI berbasis riset nasional, kemudian IAIN Lhokseumawe lebih mengharapkan individu unggul dalam pendidikan serta dapat meningkatkan pelayanan bidang PAI dalam mata kuliah metode penelitian untuk mempersiapkan peneliti dalam pembuatan thesis, IAIN Curup membagi mata kuliah metodologi penelitan menjadi empat sks berupa metodologi penelitian kualitatif dan metodologi penelitian kuantitatif. Sedangkan IAIN Lhokseumawe mata kuliah metodologo penelitian hanya 3 sks saja.

berbasis kearifan lokal, namun diantara perbedaan dua lembaga tersebut dalam perumusan visi, misi dan tujuannya sudah saling berkaitan atau berkesinambungan satu sama lain. 


\section{Daftar Pustaka}

Ali Makhrus, R. A. (2019). Manajemen Guru sebagai Upaya Pencapaian Visi-Misi Sekolah (Studi di Sekolah Menengah Atas Persatuan Guru Islam Indonesia 1 Kota Bandung). Jurnal Studi Manajemen Pendidikan Islam, 3(1).

Anisa, C. A. (2020). Visi Dan Misi Menurut Fred R . David Dalam Perspektif Pendidikan Islam. EJournal.Staima-

Alhikam.Ac.Id/Index.Php/Evalu asi DOI : Http://Doi.Org/10.32478/Evalu asi.V4i1.356 Article Type: Book Review Visi, 4(1), 70-87.

Arifin, Z. (2011). Konsep dan Model Pengembangan Kurikulum (Cet. 1). Remaja Rosdakarya.

Calam, A., \& Qurniati, A. (2016). Merumuskan Visi dan Misi Lembaga Pendidikan. Jurnal Ilmiah Saintik, 15(1), 53-68. https:// prpm.trigunadharma.ac .id/public/fileJurnal/hp1k6 MakalahFuturologi.pdf

Dzakir. (2010). Perencanaan dan Pengembangan Kurikulum. Pustaka belajar.

Farikhah, S. (2018). Manajemen Pendidikan (F. Juliantina (ed.); 2nd ed.). Aswaja Pressindo.

Fatmawati, Z., Bafadal, I., \& Sobri, A. Y. (2018). Komunikasi Kepala Sekolah Dengan Warga Sekolah Untuk Mewujudkan Visi Dan Misi Sekolah. Jurnal Administrasi Dan Manajemen Pendidikan, 1(2), 198-205. https://doi.org/10.17977/um0 27v1i22018p198

Istiqomah, H. (2020). Analisis Kepemimpinan Visioner Dalam Mewujudkan Visi Misi Sekolah Di MIN I Bantul. IBTIDA'IY: Jurnal Prodi PGMI, 5(4), 15-22. http://journal.ummat.ac.id/ind ex.php/ibtidaiy

Lazwardi, D. (2017). Manajemen Kurikulum Sebagai Pengembangan Tujuan Pendidikan. Kependidikan Islam, 7(1), 99-112.

Moleong, L. (2010). Metodologi Penelitian Kualitatif. Remaja Rosdakarya.

Muhaimin. (2010). Manajemen Pendidikan aplikasinya dalam penyusunan rencana pengembangan sekolah. KENCANA MEDIA GRUP.

Mustari, M. (2014). Manajemen Pendidikan. Raja Grafindo Persada.

Nasbi, I. (2017). MANAJEMEN KURIKULUM: Sebuah Kajian Teoritis. Idaarah: Jurnal Manajemen Pendidikan, 1(2), 318-330. https://doi.org/10.24252/idaar ah.v1i2.4274

Pramitha, D. (2016). Urgensi Perumusan Visi, Misi Dan NilaiNilai Pada Lembaga Pendidikan Islam. Jurnal Tarbawi, 01(01), 8-9.

Sudjarwo. (2011). Metodologi Penelitian Sosial. Mandar Maju. 
Sukaningtyas, D. (2017). Pengembangan Kapasitas Manajemen Sekolah dalam Membangun Pemahaman Visi dan Misi. Jurnal Cakrawala Pendidikan, 36(2), 101-107. https://doi.org/10.21831/cp.v3 $6 \mathrm{i} 2.11844$

Syafaruddin. (2017). Manajemen kurikulum. Medan : Perdana Publishing.

Tardian, A. (2019). Strategik Mutu Sekolah: Studi Kasus di SD Al Irsyad Al Islamiyyah. Jurnal Kependidikan, 7(2), 192-203. https://doi.org/https://doi.org / 10.24090/jk.v7i2.2989

Wardah, D. H. S., \& Abdul, H. (2008). Manajemen pengendalian mutu sekolah: implementasi pada sma negeri di parepare. Prosiding Seminar, 02, 66-74.

Windaningrum, F. (2019). Analisis Relevansi Visi, Misi, Tujuan, dan Kurikulum Antara SMKN 1 Kedawung Sragen dan SMKN 1 Bawen Semarang. AL-ISHLAH: Jurnal Pendidikan Islam, 17(2), 123-140.

https://doi.org/10.35905/alishl ah.v17i2.1017 